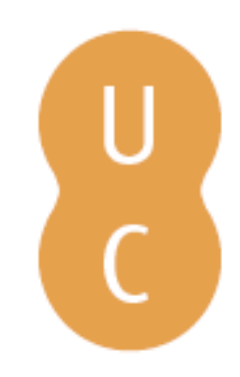

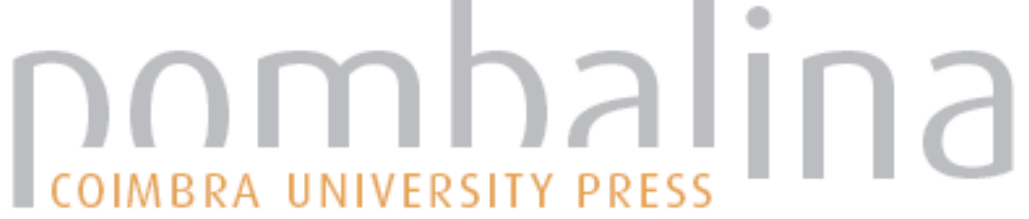

\section{Integration of the emissions and smoke dispersion models in the European Forest Fire Information System}
Autor(es):
Maianti, Pieralberto; Artés Vivancos, Tomàs; Guillaume, Bruno; Miranda, Ana Isabel; Monteiro, Alexandra; Gama, Carla; Houston Durrant, Tracy; Libertà, Giorgio; Boca, Roberto; Branco, Alfredo; de Rigo, Daniele;
Ferrari, Davide; Lana, Fabio; Costa, Hugo; San-Miguel-Ayanz, Jesús

Publicado por: Imprensa da Universidade de Coimbra

URL persistente:

URI:http://hdl.handle.net/10316.2/44632

DOI:

DOI:https://doi.org/10.14195/978-989-26-16-506_115

Accessed : $\quad$ 26-Apr-2023 15:27:29

A navegação consulta e descarregamento dos títulos inseridos nas Bibliotecas Digitais UC Digitalis, UC Pombalina e UC Impactum, pressupõem a aceitação plena e sem reservas dos Termos e Condições de Uso destas Bibliotecas Digitais, disponíveis em https://digitalis.uc.pt/pt-pt/termos.

Conforme exposto nos referidos Termos e Condições de Uso, o descarregamento de títulos de acesso restrito requer uma licença válida de autorização devendo o utilizador aceder ao(s) documento(s) a partir de um endereço de IP da instituição detentora da supramencionada licença.

Ao utilizador é apenas permitido o descarregamento para uso pessoal, pelo que o emprego do(s) título(s) descarregado(s) para outro fim, designadamente comercial, carece de autorização do respetivo autor ou editor da obra.

Na medida em que todas as obras da UC Digitalis se encontram protegidas pelo Código do Direito de Autor e Direitos Conexos e demais legislação aplicável, toda a cópia, parcial ou total, deste documento, nos casos em que é legalmente admitida, deverá conter ou fazer-se acompanhar por este aviso.

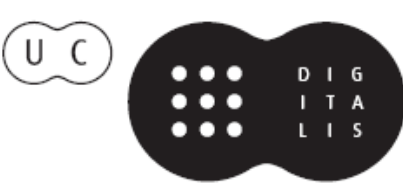




\section{ADVANCES IN}

\section{FOREST FIRE RESEARCH}

\section{8}

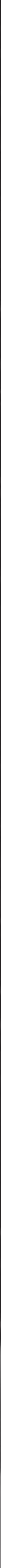




\title{
Integration of the emissions and smoke dispersion models in the European Forest Fire Information System
}

\author{
Pieralberto Maianti ${ }^{1,2 *}$; Tomàs Artés Vivancos ${ }^{2}$; Bruno Guillaume ${ }^{3}$; Ana Isabel Miranda ${ }^{4}$; \\ Alexandra Monteiro ${ }^{4}$; Carla Gama ${ }^{4}$; Tracy Houston Durrant ${ }^{2,5}$; Giorgio Libertà2 ${ }^{2}$ Roberto Boca; \\ Alfredo Branco ${ }^{1}$; Daniele de Rigo ${ }^{1}$; Davide Ferrari ${ }^{2,6}$; Fabio Lana ${ }^{1}$; Hugo Costa ${ }^{2}$; Jesús San- \\ Miguel-Ayanz ${ }^{2 *}$ \\ ${ }^{1}$ External consultant for the European Commission (ARCADIA SIT s.r.l). ARCADIA SIT s.r.l, \\ Vigevano $(P V)$, Italy. \\ ${ }^{2}$ European Commission, Joint Research Centre (JRC), Directorate for Space, Security and \\ Migration, Disaster Risk Management Unit, Ispra(VA), Italy. \{JRC-EFFIS@ec.europa.eu*\} \\ ${ }^{3}$ ARIA Technologies. 8/10, rue de la Ferme - 92100 Boulogne-Billancourt, France, \\ \{bguillaume@aria.fr\} \\ ${ }^{4}$ University of Aveiro. Campus Universitário de Santiago, 3810-193 Aveiro, Portugal, \\ \{miranda@ua.pt; alexandra.monteiro@ua.pt; carlagama@ua.pt\} \\ ${ }^{5}$ External consultant for the European Commission (GFT Italia s.r.l). GFT Italia s.r.l., Milan (MI), \\ Italy. \\ ${ }^{6}$ External consultant for the European Commission, European Dynamics, Luxembourg, \\ Luxembourg
}

\begin{abstract}
Since 2000, the European Forest Fire Information System (EFFIS) has provided continuous support and statistics on wildland fire events. The monitoring system covers all the European Countries, North Africa and the Mediterranean Countries of the Middle East, and provides information on the various aspects involved in the fire events, from fire danger forecasting to post-event analysis. One of the major impacts on the environment produced by the wildland fires is the atmospheric pollution. Currently, in EFFIS the only available information on this impact is the amount of atmospheric emissions for each fire event. The current emissions model is static and does not take into account the fire behavior during the event; moreover, it cannot distinguish the contribution of flaming and smoldering fire to the emissions. The workgroup in EFFIS is working on the current atmospheric pollution assessment system to provide a new and improved emissions model integrated with a smoke dispersion model that simulates the distribution of the pollutants in the impacted area. The new emissions estimation model will take as input the evolution of the fire events, a map of the fuel classes and forest types, a digital elevation model and the meteorological data covering the whole Europe. Based on these input data, the new emissions model simulates the behaviour of the fire using the NEXUS, FOFEM5 and CONSUME3 models, calculates the impact of the fire on the fuels and provides an assessment of the ensuing emissions. The new emissions module provides an assessment of the major pollutants emitted by fires, such as $\mathrm{CO}_{2}, \mathrm{CO}, \mathrm{CH}_{4}, \mathrm{PM}_{2.5}, \mathrm{PM}_{10}$. Large wildfires, although not very frequent, are responsible for a remarkably high percentage of the overall annual burnt area in Europe, with the highest emissions per fire event. In this paper, we present the results of the emissions estimations on the study case of a representative large wildfire event that took place in Zamora (Spain) during the 2017 fire season. The dispersion model, developed along with the new emissions module, takes as an input the output of the emissions model and provides a simulation of the dynamic of the smoke plume for each of the aforementioned pollutants. The dispersion module is a framework of integrated models able to estimate the dispersion of fire plumes in the atmosphere in 3D grid format. There are four main modules: WRF is dedicated for the computation of the meteorological background data, SWIFT for the higher resolution focus on a specific study area, CHIMERE for the assessment of the concentration of the background pollutants at regional scale,
\end{abstract}


and SCICHEM for the simulation at local scale of the smoke plume of a selected event. The output of the model is a series of NetCDF files (one for each of the pollutants taken into account) that simulate the 3D spatial and temporal development of the smoke plume. The application of the dispersion model on the Zamora study case shows an example of the output product.

Keywords: Forest fires; Wildfires; Atmospheric emissions modelling; Pollutant dispersion; EFFIS.

\section{Introduction}

Since 2000, the European Forest Fire Information System (EFFIS, http://effis.jrc.ec.europa.eu/) of the European Commission, Joint Research Centre (JRC) has systematically delivered information and statistics of burnt areas mapped from satellite imagery (San-Miguel-Ayanz et al., 2013). It is a complex monitoring system covering all the European Countries, North Africa and the Mediterranean Countries of the Middle East. EFFIS is able to collect and disseminate information on the many aspects involved in the fire events, from fire danger forecasting to post-event analysis.

The impact of forest fires on air quality is progressively concerning the population of the main affected areas (Cornwall, 2018; Finlay et al., 2012; Carvalho et al., 2011; Stefanidou et al., 2008). Forest fire smoke can be synonymous of severe crisis, which in recent years increased the number of hospitalizations for respiratory diseases (Wegesser et al., 2009; Ignotti et al. 2010). The integration of the new fire emissions and smoke dispersion modules in EFFIS will provide improved tools for air quality assessment both at local and European scale. The new emissions module will take into account the evolution of the burned areas mapped on a daily basis, and provides an assessment of the major pollutants emitted by fires, such as $\mathrm{CO}_{2}, \mathrm{CO}, \mathrm{CH}_{4}, \mathrm{PM}_{2.5}$, and $\mathrm{PM}_{10}$. The output of the new emissions module will be the input of the dispersion module, which provides the dynamic of the smoke plume for each of the aforementioned pollutants on selected severe fire events. The objective of this paper is to describe the components and the workflow of the new emissions and dispersion models, and to present their application on a study case.

\section{Emissions module}

\subsection{Module description}

The current version of the emissions module in EFFIS estimates the concentration of pollutants (Barbosa et al., 2008; Monteiro et al., 2014) relying on classical methodologies of fuel map-based computation and constant burning efficiencies given by fuel types (San Miguel et al., 2011). In order to better reproduce the complex behaviour of the phenomenon, this model has been restyled, updated and integrated in recent years.

In the new version of the model, a richer set of features is considered:

- Burnt areas and their evolutions provided by EFFIS daily mapping (in the current model only the final burnt area is considered);

- Digital Terrain Model, fuel composition (JRC forest types static maps) and meteorological data from the European Centre for Medium-Range Weather Forecast (ECMWF);

- Evaluation of the key variables fuel moisture (provided by the Live Fuel Moisture Content, LFMC model), fireline intensity and fire rate of spread (NEXUS model, Scott, 1999, Scott and Reinhardt, 2001);

- Assessment of burning efficiencies and amounts of fuel burned or consumed during the different combustion phases (provided by the models CONSUME3, Prichard et al., 2005, Ottmar et al., 1993; and FOFEM5, Keane et al., 1995, Reinhardt and Dickinson, 2010, Prichard et al., 2014); 
- Emissions estimations from burned fuel loadings applying emission factors taken from the "European biomass burning" (Miranda et al., 2005).

The workflow of the module is represented in Figure 1. The main application of the Emissions module is the daily estimation of the pollutants, which is based on the preliminary mapping of the burnt areas. It is scheduled at 1:00 AM of the day following a burnt area detection, and takes into account the perimeters detected during the previous day. As the definition of the perimeters can be reviewed and corrected, a second typology of the module usage is the reanalysis mode, which consists of a simulation run usually performed at the end of a fire season. The reanalysis mode takes as an input the final perimeters in order to obtain the definitive assessment of the emissions.

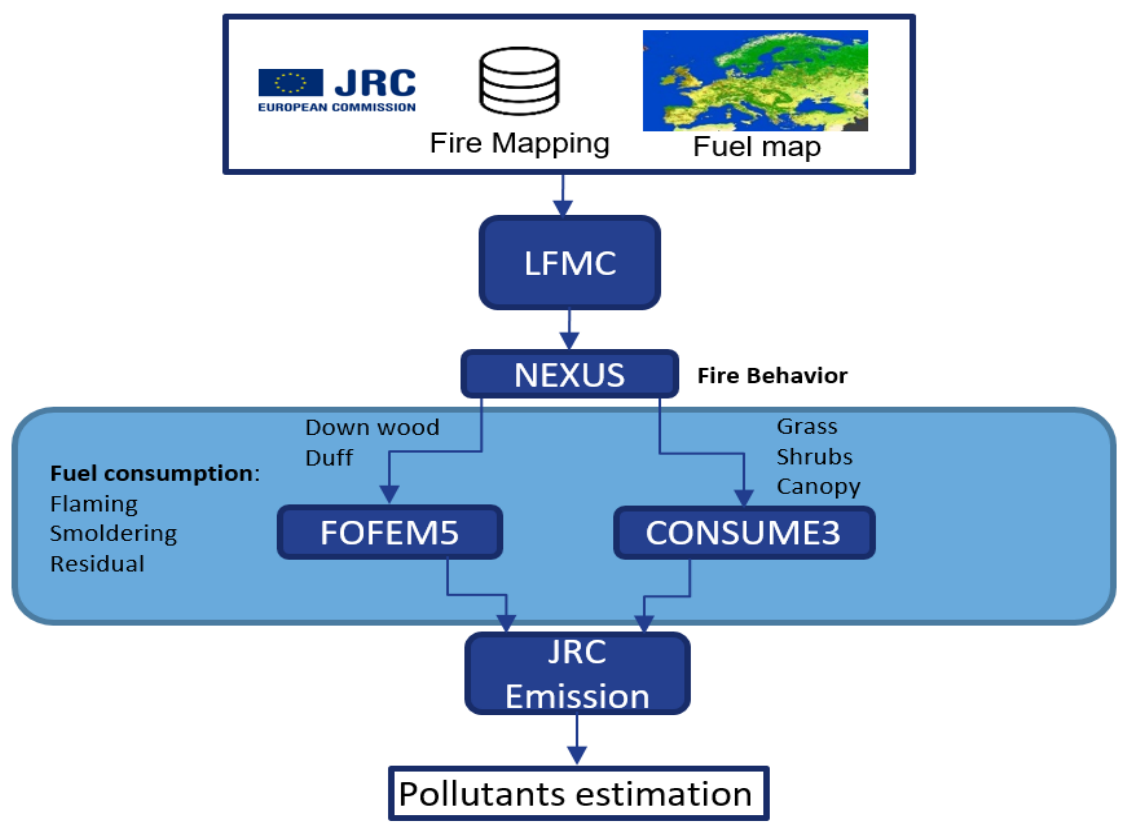

Figure 1 - Emissions module workflow.

When applied for the evaluation of the emissions produced within a burnt area, the new emissions module provides a shapefile with the geometry of the input burnt areas and lists in the associated attribute table the estimated concentrations of the pollutants. For each of these polluting components (Table 1), the module simulates the evolution of the concentrations produced (measured in $10^{3} \mathrm{~kg}$ ) over the day of fire activity with a time step of three hours (from 0 to 24). Compared to the current model, the new version expands the set of output variables and provides an assessment for the $\mathrm{SO}_{2}$, $\mathrm{NH}_{3}, \mathrm{BaP}, \mathrm{LVGC}$ pollutants (see list on Table 1).

Table 1 - List of the variables (aggregated) reported in the emissions simulation module.

\begin{tabular}{llllllll}
\hline $\begin{array}{l}\text { Variable } \\
\begin{array}{l}\text { Extended } \\
\text { name }\end{array}\end{array}$ & $\begin{array}{l}\mathbf{C O}_{2} \\
\text { Dioxide carbon }\end{array}$ & $\begin{array}{l}\text { CO } \\
\text { Monoxide } \\
\text { carbon }\end{array}$ & Methane & $\begin{array}{l}\mathbf{C H}_{4} \\
\begin{array}{l}\text { Particulate } \\
\text { matter } \\
\leq 2.5 \mu \mathrm{m}\end{array}\end{array}$ & $\begin{array}{l}\text { Particulate } \\
\text { matter } \leq 10 \mu \mathrm{m}\end{array}$ & $\begin{array}{l}\text { Non-methane } \\
\text { hydrocarbons }\end{array}$ & $\begin{array}{l}\text { Volatile } \\
\text { Organic } \\
\text { Compounds }\end{array}$ \\
\hline $\begin{array}{l}\text { Variable } \\
\begin{array}{l}\text { Extended } \\
\text { name }\end{array}\end{array}$ & $\begin{array}{l}\mathbf{N O}_{\mathbf{x}} \\
\text { Nitrogen } \\
\text { Oxides }\end{array}$ & OC & Organic carbon & Black Carbon & Sulphur dioxide Ammonia & $\begin{array}{l}\text { Benzo(a)- } \\
\text { pyrene }\end{array}$ & Levo-glucosan \\
\hline
\end{tabular}

As ancillary information, the module also reports the following variables:

- Fire intensity (in $\mathrm{kW} \mathrm{m}^{-2}$ ), which is used as input in the dispersion module to estimate the maximum height of injection of the emissions in the atmosphere; 
- Fuel consumption in the fire phases of flaming (fire front) and smouldering (after the passage of the fire front), expressed in $\mathrm{kg}$ of fuel / 3hours;

- Area increase over each 3 hours time step, assumed proportional to the 3 hours average rate of spread of the fire, expressed in $\mathrm{m}^{2} / 3$ hours.

\subsection{Study case results}

In cases where the fire event takes two or more days of burning activity, and as long as the clouds conditions and smoke presence allow constant monitoring, the mapping activity can theoretically detect the evolution of the event on a daily basis. When these conditions are present, the emissions module estimates the amount of emissions for each day of the mapping.

As an example of the emissions and dispersion modules application, in this paper we report the test case of the fire that took place in Zamora province (Spain) during the day 29/07/2017 and concluded on 30/07/2017 (Figure 2). This study case is representative of a large wildland fire in Europe. Although the number of large wildfires represent a small proportion of the total fire events in Europe, their impact is disproportionally high. Large wildland fires are also the most endangering and impactful for the population. In the Fire Database of EFFIS (a repository of over 2 million individual fire records from 24 countries in Europe and North Africa), the wildfires larger than 1000 ha represent only $0.1 \%$ of the recorded fire events, but are responsible for $30 \%$ of the total burnt area. Only less than $0.02 \%$ of the wildfires spread over 3000 ha: however, this small percentage contributes $16 \%$ of the total damaged area in Europe (Camia et al., 2014; de Rigo et al., in prep.).

The wildfire in Zamora spread over a total burnt area of 3087 ha (EFFIS source). In this case, it was not possible to follow the evolution of the fire during the development of the event due to smoke plume coverage on the area, which impeded the constant monitoring during the days of activity, and the speed of the fire spread and consumption.

Table 2 reports the output of the new fire emissions model, along with those provided by the static model currently used by EFFIS for the emissions assessment. For the variables $\mathrm{SO}_{2}, \mathrm{NH}_{3}, \mathrm{BaP}, \mathrm{LVGC}$ there is no information provided by the current model and no comparison was therefore possible.

Table 2 - Emissions estimations for the test case of wildfire in Zamora province (Spain).

\begin{tabular}{|c|c|c|c|c|c|c|c|c|c|c|c|c|c|c|}
\hline Variable & $\mathrm{CO}_{2}$ & CO & $\mathbf{C H}_{4}$ & $\mathbf{P M}_{2.5}$ & $\mathbf{P M}_{10}$ & NMHC & VOC & $\mathrm{NO}_{\mathbf{x}}$ & OC & $\mathrm{BC}$ & $\mathbf{S O}_{2}$ & $\mathbf{N H}_{3}$ & $\mathrm{BaP}$ & LVGC \\
\hline $\begin{array}{l}\text { New emission } \\
\text { model }\left(\mathrm{kg} \cdot 10^{3}\right)\end{array}$ & 69180 & 3450 & 139 & 335 & 374 & 387 & 263 & 233 & 228 & 37 & 49 & 25 & 1 & 15 \\
\hline $\begin{array}{l}\text { Static model } \\
\left(\mathrm{kg} \cdot 10^{3}\right)\end{array}$ & 54875 & 2466 & 126 & 238 & 281 & 102 & 123 & 172 & 140 & 16 & - & - & - & - \\
\hline $\begin{array}{l}\text { Variation } \\
\text { Static } \rightarrow \text { New }(\%)\end{array}$ & 26 & 40 & 10 & 41 & 33 & 279 & 114 & 36 & 63 & 128 & - & - & - & - \\
\hline
\end{tabular}

In the described study case, the new emissions model provides values of pollutant emissions greater than those estimated by the current one. The most remarkable increases are those recorded on NMHC, VOC and BC, for which the estimations result higher than $100 \%$ compared to the ones of the current model. The consistency of the increase may be due to the contribution brought by the smouldering fire, which is taken into account with the new model. 


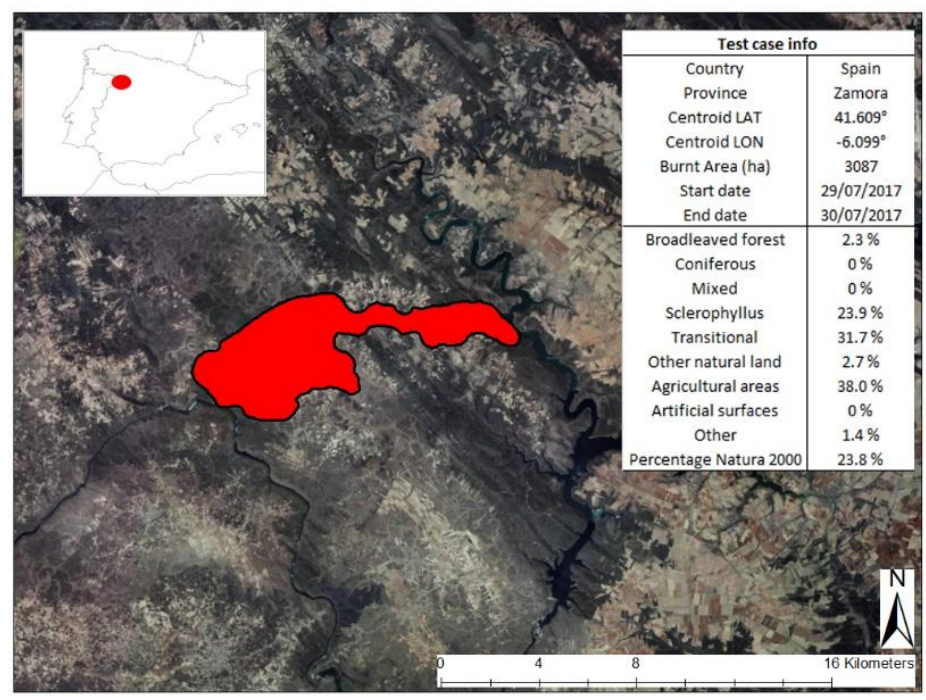

Figure 2 - Localization, shape and ancillary information on the test case in Zamora (Spain).

\section{Dispersion module}

\subsection{Module description}

The smoke plume dispersion module is a new feature developed along and integrated with the new emissions module. It consists of a framework of integrated models that take as input the emissions generated by the new emissions module, and simulates over time in 3D grid format their dispersion plumes in the atmosphere. The processing is applied only on selected severe wildland fire events, for which the smoke plume modelling or post-event analysis is of particular interest. The four main modules of the framework are:

- WRF: Weather Research and Forecasting model;

- CHIMERE: Chemistry-transport model;

- SWIFT: Stationary Wind Field and Turbulence;

- SCICHEM: Second-order Closure Integrated puff model with CHEMistry.

The WRF model (Michalakes et al., 2005) is assigned to the computation of the meteorological background data at regional scale (European continent), and SWIFT to the local focus on a specific selected study area. The concentration of the pollutants is then assessed by CHIMERE (Bessagnet $e t$ al., 2004) (for the regional pollutant background assessment), while the evolution of the plume at local scale by SCICHEM (Chowdhury et al., 2015) (Figure 3). The final output of the dispersion module is a series of Network Common Data Form (NetCDF) files (one for each of the pollutant emissions generated by the emissions module) that simulate the 3D spatial and temporal development of the smoke plume with a time step of 3 hours. 


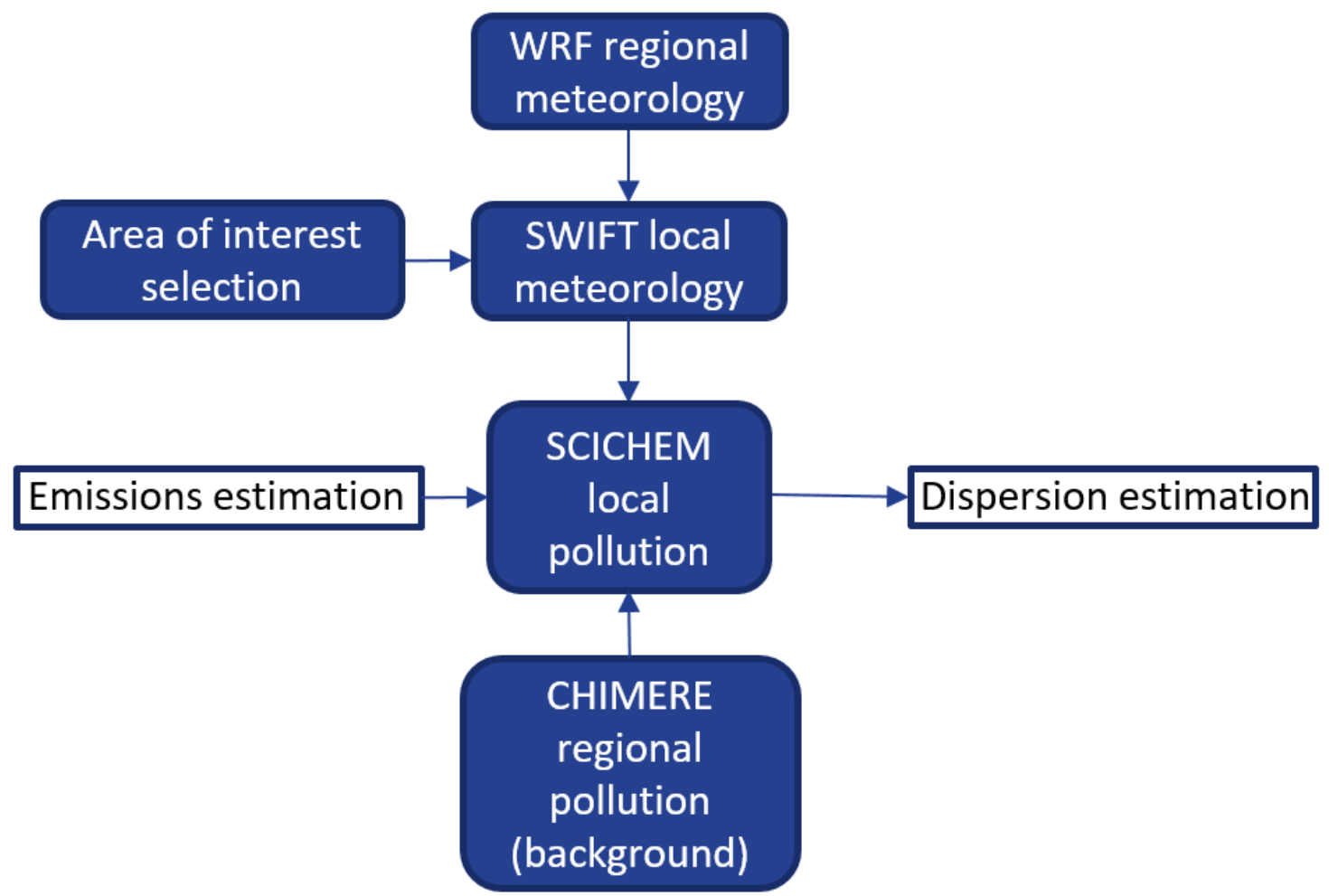

Figure 3 - Dispersion module workflow

\subsection{Study case results}

The Zamora (Spain) fire event was taken into account for the representation of the dispersion of pollutants on an area of approximately $70 \times 70 \mathrm{~km}^{2}$ surrounding the centroid of the burnt area. The simulation was performed setting a grid sampling resolution to $1 \mathrm{~km}$ in $\mathrm{X}$ and $\mathrm{Y}$ directions, and $0.5 \mathrm{~km}$ in $\mathrm{Z}$ from the ground level. Figure 4 shows the spatial representation of the concentration of the $\mathrm{CO}$ emissions produced by the fire in Zamora, values of which were estimated and reported in Table 2. The maps shown are centered in the centroid of the burnt area, and the plots show the evolution of the smoke plume dispersions during the 24 hours of the day 29/07. The CO dispersions in Figure 4 are related to the ground level, which is the one of greatest interest due to the impacts of the pollution on the population.

The following Figure 5 represents the progression of $\mathrm{CO}$ concentrations in time steps (top to bottom in columns) and height (left to right in the rows; ground level, 500 and $1000 \mathrm{~m}$ ). 


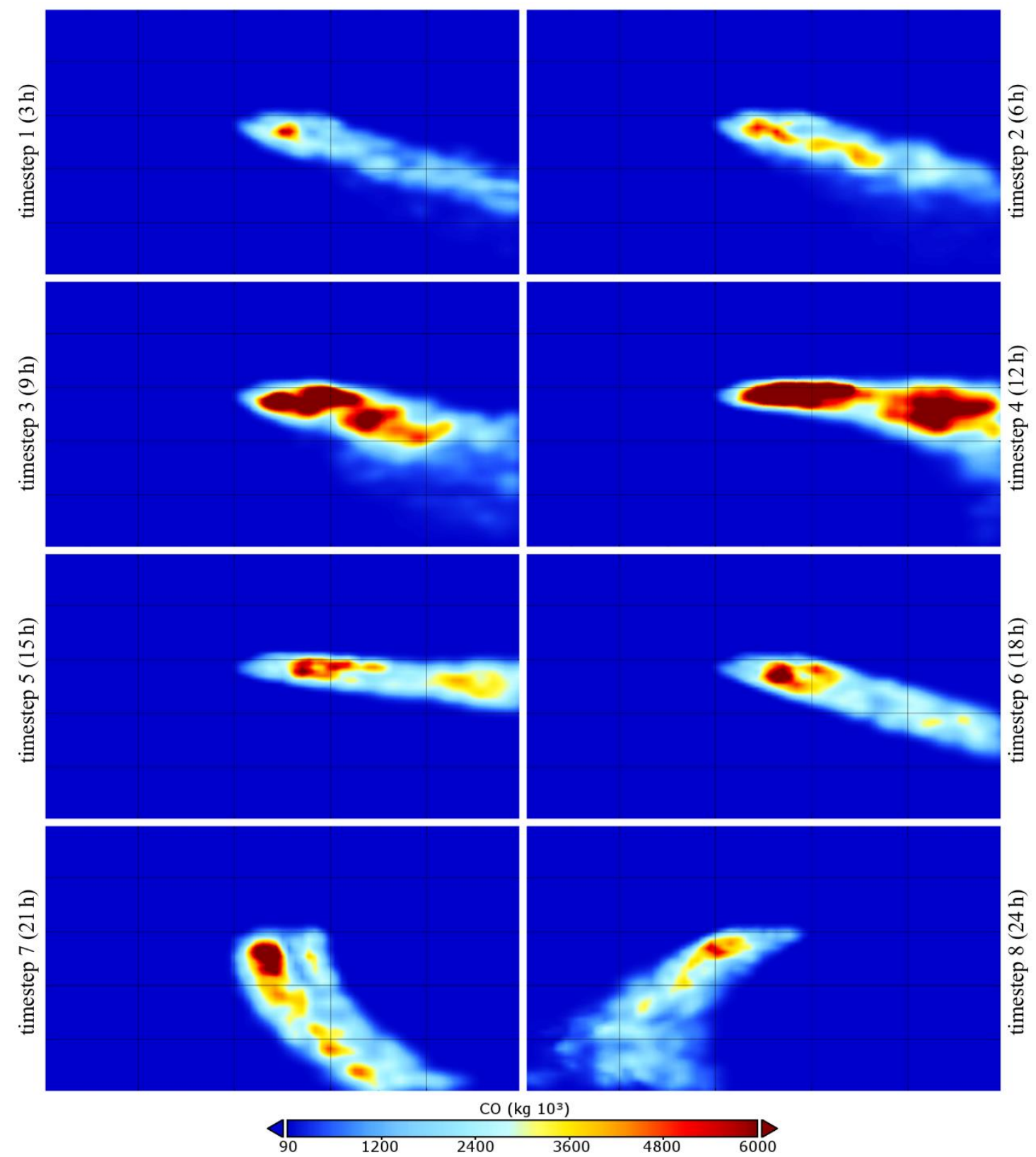

Figure 4 - Progression of the concentration of $\mathrm{CO}$ at ground level produced by the wildfire in Zamora (2930/07/2017). 


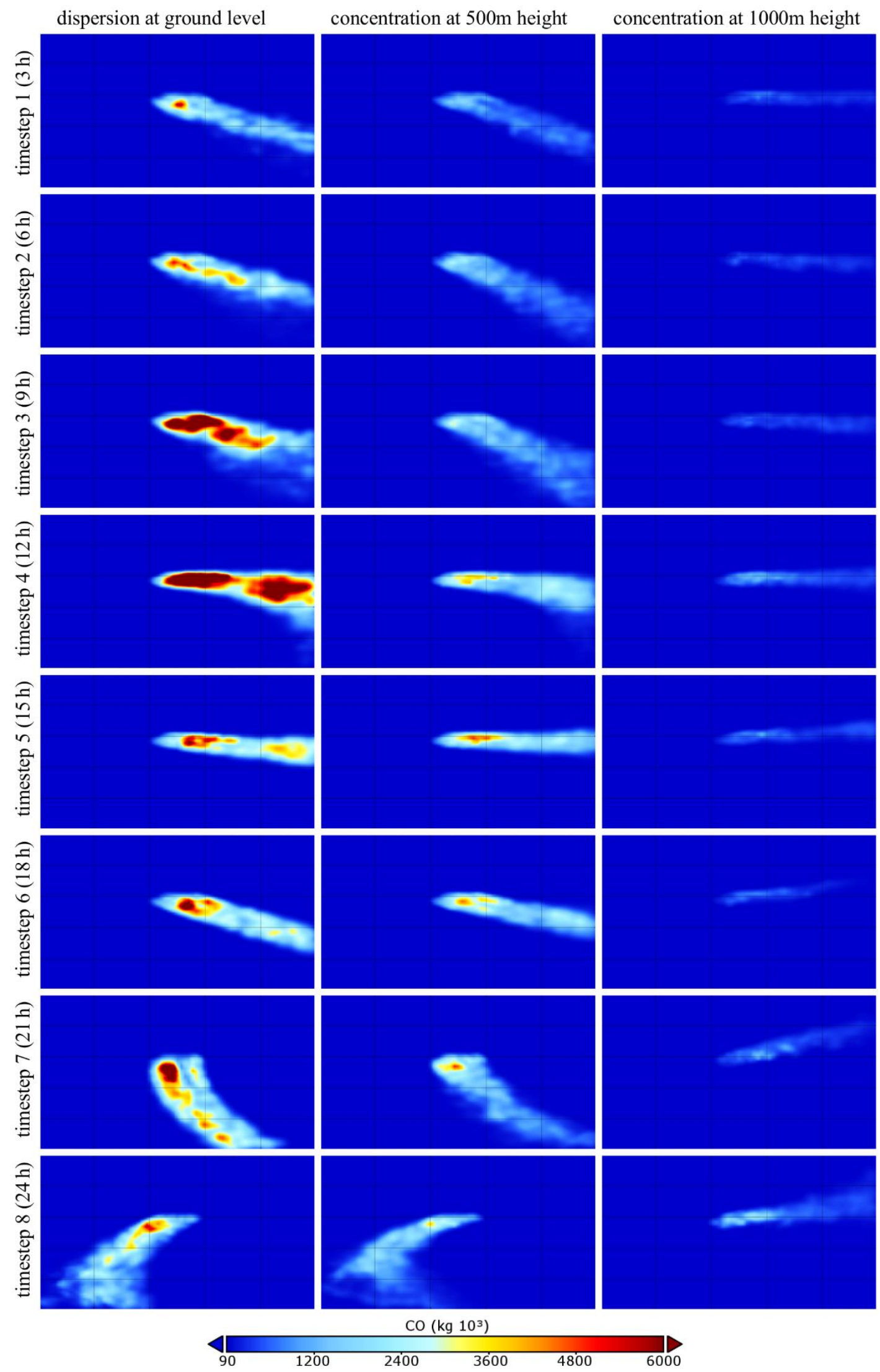

Figure 5 - Dynamics of CO concentrations in timesteps (top to bottom in columns) and height (left to right in the rows) simulated for the Zamora fire episode (29-30/07/2017).

The last step of the processing is the conversion of the resulting concentrations in GeoJSON format isolines for easier visualization on webmaps.

Advances in Forest Fire Research 2018 - Page 1050 


\section{Conclusions and way forward}

The integration of the new fire emissions and dispersion modules in EFFIS will provide a unique tool for the assessment of the air pollution caused by forest fires in Europe. The resulting information at regional and local scale will be extremely valuable for integrated-assessment applications both during the fire season and in post-event analysis (Lentile et al., 2006; de Rigo et al., 2013; Di Leo et $a l ., 2013$ ). On the study case fire event of Zamora (Spain), the comparison of the new with the current emissions model used in EFFIS shows a consistent increase in the estimation of the concentration for each one of the pollutants, with three peaks in NMHC, VOC and BC. The application of the dispersion model on the outputs of the emissions model will also provide a 3D assessment of the evolution of the smoke plume trajectory. The spatial distribution of the concentrations at ground level represents valuable information on the impact of the smoke plume pollutant on the population resident in the surrounding area. The next steps of the project will consist of the comparison with field data on various test cases and the Sentinel-5P atmospheric pollution estimations. This will be the basis for a biasadjustment module to be added, so as for the field information to improve the physically based estimations of the fire emission and dispersion modules in EFFIS. At last, the dissemination of the results for each fire season in the EFFIS web application will be available.

\section{References}

Barbosa P, Camia A, Kucera J, Libertà G, Palumbo I, San-Miguel-Ayanz J, Schmuck G (2008). Assessment of forest fire impacts and emissions in the European Union based on the European Forest Fire Information System. Vol. 8 of Developments in Environmental Science. Elsevier, pp. 197-208.

Bessagnet B, Hodzic A, Vautard R, Beekmann M, Cheinet S, Honoré C, Liousse C, Rouil L (2004). Aerosol modelling with CHIMERE: preliminary evaluation at the continental scale. Atmospheric Environment 38, 2803-2817.

Camia A, Houston Durrant T, San-Miguel-Ayanz J (2014). The European Fire Database: technical specifications and data submission. Publications Office of the European Union, Luxembourg.

Carvalho A, Monteiro A, Flannigan M, Solman S, Miranda AI, Borrego C (2011). Forest fires in a changing climate and their impacts on air quality. Atmospheric Environment 45 (31), 5545-5553.

Chowdhury B, Karamchandani PK, Sykes RI, Henn DS, Knipping E (2015). Reactive puff model SCICHEM: Model enhancements and performance studies. Atmospheric Environment 117, 242258.

Cornwall W (2018). Scientists aim to smoke out wildfire impacts. Science 360 (6392), 948-949.

de Rigo D, Costa H, Libertà G, Houston Durrant T, San-Miguel-Ayanz J (2018). European wildfire danger and damage in a changing climate: towards integrating risk dimensions. Publication Office of the European Union, Luxembourg, (in preparation).

de Rigo D, Rodriguez-Aseretto D, Bosco C, Di Leo M, San-Miguel-Ayanz J (2013). An architecture for adaptive robust modelling of wildfire behaviour under deep uncertainty. IFIP Advances in Information and Communication Technology 413, 367-380.

Di Leo M, de Rigo D, Rodriguez-Aseretto D, Bosco C, Petroliagkis T, Camia A, San-Miguel-Ayanz J (2013). Dynamic data driven ensemble for wildfire behaviour assessment: a case study. IFIP Advances in Information and Communication Technology 413, 11-22.

Finlay SE, Moffat A, Gazzard R, Baker D, Murray V (2012). Health impacts of wildfires. PLoS Currents Disasters, 1881+. 
Ignotti E, Hacon SS, Longo K, Freitas S, Mourao DS, Junger WL, Artaxo P (2010). Air Pollution and Hospital Admissions for Respiratory Diseases in the Subequatorial Amazon: A Time Series Approach. Cadernos de Saúde Pública (ENSP. Impresso), 26, 747-761.

Keane, RE, Reinhardt, ED, \& Brown, JK (1995). FOFEM: a first order fire effects model. General technical report INT (USA).

Lentile LB, Holden ZA, Smith AMS, Falkowski MJ, Hudak AT, Morgan P, Lewis SA, Gessler PE, Benson NC (2006). Remote sensing techniques to assess active fire characteristics and post-fire effects. International Journal of Wildland Fire 15 (3), 319+.

Michalakes J, Dudhia J, Gill D, Henderson T, Klemp J, Skamarock W, Wang W (2005). The Weather Research and Forecasting Model: software architecture and performance. Proceedings of the Eleventh ECMWF Workshop on the Use of High Performance Computing in Meteorology, 156168.

Miranda AI, Ferreira J, Valente J, Santos P, Amorim JH, Borrego C (2005). Smoke measurements during Gestosa 2002 experimental field fires. International Journal of Wildland Fire 14, 107-116.

Monteiro A., Corti P., San-Miguel-Ayanz J., Miranda A. I., Borrego C. (2014). The EFFIS forest fire atmospheric emission model: application to a major fire event in Portugal. Atmospheric Environment 84, 355-362.

Ottmar, RD, Burns, MF, Hall, JN, Hanson, AD (1993). CONSUME: users guide. Gen. Tech. Rep. PNW-GTR-304. Portland, OR: U.S. Department of Agriculture, Forest Service, Pacific Northwest Research Station.

Prichard SJ, Ottmar RD, Anderson GK (2005). Consume 3.0 User's Guide, United States Department of Agriculture Forest Service, Pacific Northwest Research Station, Seattle. WA.

Prichard, SJ, Karau, EC, Ottmar, RD, Kennedy, MC, Cronan, JB, Wright, CS, \& Keane, RE (2014). Evaluation of the CONSUME and FOFEM fuel consumption models in pine and mixed hardwood forests of the eastern United States. Canadian journal of forest research, 44(7), 784-795.

Reinhardt, ED, \& Dickinson, MB (2010). First-order fire effects models for land management: overview and issues. Fire Ecology. 6(1), 131-142.

San Miguel-Ayanz J, Schulte E, Schmuck G, Camia A, Strobl P, Liberta G, Giovando C, Boca R, Sedano F, Kempeneers P, McInerney D, Withmore C, Santos de Oliveira S, Rodrigues M, Durrant T, Corti P, Oehler F, Vilar L, Amatulli G (2011). Comprehensive monitoring of wildfires in Europe: The European Forest Fire Information System (EFFIS), in Tiefenbacher, J. (Ed.) Disaster Management, ISBN 978-953-307-651-5.

San-Miguel-Ayanz J, Schulte E, Schmuck G, Camia A (2013). The European Forest Fire Information System in the context of environmental policies of the European Union. Forest Policy and Economics 29, 19-25.

Scott, JH (1999). NEXUS: a system for assessing crown fire hazard. Fire Management Notes.

Scott JH, Reinhardt ED (2001). Assessing crown fire potential by linking models of surface and crown fire behavior. Res. Pap. RMRS-RP-29. Fort Collins, CO: Introduction to Wildfire Behavior Modeling Appendix A 143 U.S. Department of Agriculture, Forest Service, Rocky Mountain Research Station.

Stefanidou M, Athanaselis S, Spiliopoulou C (2008). Health impacts of fire smoke inhalation. Inhalation Toxicology 20 (8), 761-766.

Wegesser TC, Pinkerton KE, Last JA (2009). California Wildfires of 2008: Coarse and Fine Particulate Matter Toxicity. Environmental health perspectives 117 (6), 893-897. 